\title{
Assessment of ethanol as fuel additive to diesel-biodiesel blends on emission characteristics in CI engine
}

\author{
K. Rajesh ${ }^{1 *}$ and Ganesh D.B ${ }^{2}$ \\ Associate Professor, Department of Mechanical Engineering, STJ Institute of Technology, Ranebennur, Karnataka, \\ India $^{1}$ \\ Professor and Dean, Department of Mechanical Engineering, GM Institute of Technology, Davangere, Karnataka, \\ India $^{2}$
}

Received: 04-January-2019; Revised: 16-March-2019; Accepted: 21-March-2019

(C)2019 K.Rajesh and Ganesh D.B. This is an open access article distributed under the Creative Commons Attribution (CC BY) License, which permits unrestricted use, distribution, and reproduction in any medium, provided the original work is properly cited.

\begin{abstract}
The diesel engine has a higher enduring and thermal efficiency than the spark ignition (SI) engine. In order to partially replace the diesel, biodiesel incorporated diesel is used in the compression ignition engine to meet the growing demand for the energy. Biodiesel is not the only alternative solution. It is renewable, its use allows reductions in oxides of nitrogen and carbon into the atmosphere. In contrast with diesel, the elevated blend (diesel \& biodiesel) kinematic viscosity affects the atomization of fuel in the combustion which reduces the combustion pressure and temperature. Addition of ethanol in the blends of biodiesel-diesel enhances the hot flow, cold flow, thermo-physical properties and oxygen content of the biodiesel incorporated burning fuel. By the experiments, it is concluded that, for all blends nitric oxide emission is less than pure diesel this may be because of the increase in the percentage of oxygen, which is being contributed from both pongamia biodiesel and ethanol which further reduces the nitric oxide emission. In contrast to a biodiesel blend, hydrocarbons (HC) emission of biodiesel blend containing ethanol is slightly more but less than mineral diesel. The carbon monoxide (CO) emissions increased as ethanol concentration increases in the burning fuel. As engine load increases, smoke opacity increases. But for the higher concentration blends, smoke opacity is somewhat superior with respect to diesel fuel for lower loads. In this paper, assessment of ethanol as fuel additive to biodiesel incorporated diesel burning fuel on tail end emission characteristics in compression-ignition (CI) engine is reported.
\end{abstract}

\section{Keywords}

IC engine, Ethanol, Bio diesel, Emission.

\section{Introduction}

By 2035, population growth of the world is expected to boost almost 1.5 billion people to reach 8.8 billion [1]. Growth in the population and world economy drives the energy demand, energy demand increases by $30 \%$ [1]. In spite the popularity of the alternative fuels, natural gas and electricity in the transport sector, oil remains the main propelling fuel in the transport sector. Transport sector remains the major driving force of overall growth in the demand accounting $50 \%$ of the overall demand ( $8 \mathrm{MB} /$ day). Demand within the transport sector is mainly driven by the trucks and non-road consummation [2]. With an increase in the population, economic activities, India are the main driving factor in the global energy demand.

\footnotetext{
*Author for correspondence

As compared to China, India energy demand growth is almost 3 times higher, accounting more than a $75 \%$ of the global increase in the demand [2]. By the year 2035, fossil fuel (coal, oil, gas) remains the leading contributors to global energy needs. By the year 2040 global demand for petroleum oil and other liquid fuels projected around 13MB/day, reaching 109 $\mathrm{MB} /$ day [2].

The global demand for liquid fuels, state of affairs of an environmental issue, and increase in population did the researchers to search for alternative fuel. An alternative fuel, which promises a pleasant correlation with sustainable development, energy conservation, management, efficiency and environmental preservation. 
Considering the varies resources, biodiesel is a most promising compared to fossil fuel as it forms lower carbon and smoke keeping the environmental issues. Biodiesel has become a most promising alternative source of energy for environmental benefits such as non-hazardous and ecological friendly [3, 4]. By using biodiesel, the tail end emissions emitting from the compression ignition engine can be reduced significantly. Biodiesel promotes the perfect combustion of burning fuel, which in turn increases the chamber temperature. Increase in the oxygen quantity because of the biodiesel in the burning fuel together with elevated chamber temperature promotes the increase in tendency of creation of oxides of nitrogen (NOx) [5-7]. Use of biodiesel in CI engine has fuel flow, lubricating and structural troubles [7].

In contrast to diesel, the injected droplets of the blend (diesel and biodiesel) exhibit high size (diameter) because of the viscosity and surface tension of the blend (diesel and biodiesel). As the biodiesel ratio increases in the blend, then the droplet size also increases [8]. The atomization of biodiesel-diesel blends in the chamber are less with reference to diesel owing the higher kinematic viscosity of blends which further reduces the pressure, temperature and engine output [9]. Jatropha and Pongamia spray pattern are found to be weakly atomized and intact liquid cores were observed even at an injection pressure of 1600 bar. Injection delays were observed to be much higher than diesel. This is due to the high viscosity and surface tension [10].

Thermo-physical qualities and cold flow of diesel fuel blended with biodiesel was intensified by adding ethanol to diesel fuel blended with biodiesel. As ethanol has a $34 \%$ by weight oxygen, which acts as a source of oxygen for the burning fuel with less cost. Enhanced combustion was noticed in [11] because of ethanol which reduces the viscosity and increases the percentage of oxygen in the burning fuel.

From early 1980s the use of ethanol along with the diesel in the CI engine was the focus of research and some research shown that use of ethanol along with diesel is suitable for $\mathrm{CI}$ engine without any modification $[12,13]$. Because of the technical, economical barrier and cost factor ethanol is not considered. Improvement of technology, reduction of production cost, government policies and energy crisis renewed the interest in ethanol use in the diesel-biodiesel blend.
De et al. [14], used ethanol in the diesel in the ratio of $10 \%, 15 \%$ and $20 \%$ along with the additives for cetane number improvements and the stabilization of burning fuels. For all blend's ethanol addition keep the cetane number well above the 45 . It was reported that the $10 \%$ addition of ethanol in biodiesel incorporated diesel showed the slight decrease in higher power output at complete load this may be because of a reduction of $5 \%$ calorific value of the burning fuel. Decrease in calorific value of the burning fuel also increases brake-specific fuel consumption (BSFC) as compared to neat diesel [16]. Brake thermal efficiency (BTE) for the diesel-ethanol blend is the same or slightly higher than diesel as compared to pure diesel [16]. This may be because of the longer ignition delay of diesel-ethanol mixture which results in higher amounts of burning fuel participate in the constant volume combustion and hence loss of heat is less.

He et al. [15], used 10\% [E10] and 30\% [E30] ethanol in diesel-ethanol blends. Added additives and ignition improver blend to the E10 and E30 blends [E10A and E30A]. Cetane number is curtailed by $10 \%$ and $50 \%$ for E20 and E30 blends respectively. Upon adding additives, an improvement of $10 \%$ and $80 \%$ for the E10A and E30A blends respectively. During the emission test on the Diesel engine, it is found that $6.3 \%$ and $43.8 \%$ reduction in the smoke for E10A and E30A respectively in relation to petroleum diesel [E0]. The identical tendency was emphasized in $[16,17]$ they attributed this to oxidization by a locally rich zone of oxygen, which is created by the elevated ethanol proportion in the burning fuel. More amount of heat is needed for the ethanol vaporization and the traces of water in the diesel-ethanol blends, at the elevated load, reduces the cylinder peak temperature which in turn reduces the NOx formation [15, 17].

NOx emission by the diesel-ethanol blend is the same or slightly less than diesel [16]. They attributed this to oxygen content and ignition delay, even though oxygen content is more in diesel-ethanol blends, but because of the lower heating value and more ignition delay lead to the accumulation of fuel which results in elevated temperature of the chamber which promote NOx formation within the chamber.

For the diesel-ethanol blends, total hydrocarbon (THC) and $\mathrm{CO}$ emissions were more than that of petroleum diesel. However, using additives and ignition improvers the THC emission was found to be less than that petroleum diesel [15]. 
Since ethanol needs more heat to vaporize which produce poor evaporation phase by the chamber becomes cooler leading to the poor atomization this may lead to a collision of injected fuel on the walls of the chamber which leads to the higher emission of THC [16].

Park et al. [17], experimentally investigated the spray pattern of CI engine by using diesel and ethanol incorporated diesel. As ethanol blending ratio increases the spray tip dispersion reduces. In contrast to the diesel fuel, ethanol incorporated diesel with $10 \%$ and $20 \%$ of the ethanol exhibits reduction in spray tip dispersion about $5.4 \%$ and $8.6 \%$ respectively. As the spray cone angle is inversely proportional to the oil density, hence the spray cone angle exhibits the rising pattern with the ethanol blending.

Diesel, ethanol blends need the organic additives to stabilize the mixture [14]. The higher amount of ethanol requires the fumigation which involves the difficult to control the device $[18,19]$. As ethanol has a higher heat absorption per $\mathrm{kg}$ of fuel, because of this cold start need more energy which leads to starting problems. Hence, external energy required for the primary fuel vaporization [20].

The problems of using biodiesel incorporated diesel and ethanol incorporated diesel in a diesel engine can be overcome by using both biodiesel and ethanol along with the diesel in compression ignition engine. Some of the research is fascinating towards the blending the ethanol to the diesel-biodiesel blends. The on-going research programs and the previously proven studies aiming at the partial substitution of diesel with biodiesel and ethanol mixture in diesel engines. Established facts are found to be encouraging because this mixture has the matching fuel properties similar to diesel with elevated content of biofuel.

Hulwan and Joshi [21], verified the feasibility of the high percentage ethanol incorporated burning fuel (diesel and biodiesel) with different proportion. The heat release rate of these blends deferred at low loads, but approaches to the diesel fuel at high loads. They attributed this to the mass of premixed burned fuel increases with load. Influence of low cetane number on ignition delay reduces at higher loads. At elevated engine loads maximum cylinder pressure remains constant, whereas for low engine loads the maximum cylinder pressure decreases [22].
Burning fuel ignition delay increases with an increase in the ethanol content in the burning fuel [21]. About $40-50 \%$ increase in the ignition delay reported for the higher ethanol content blends. Further, it is noticed that low cetane rating, high heat absorption per $\mathrm{kg}$ of ethanol incorporated burning fuel results in higher ignition delay [22-25]. However, ignition delay for ethanol blended fuels; decrease in elevated load as the auto-ignition of the ethanol incorporated burning fuels was enhanced by the increased pressure and temperature [26]. Because of the low compressibility of alcohol blended fuel, the start of injection about 2 to $3 \%$ earlier than the diesel fuel and injection pressure also rises rapidly [26].

Lower BSFC for alcohol incorporated burning fuel as compared to the biodiesel incorporated diesel fuel (B30 ), this may be because of an increase in the distribution speed of the air / fuel mixture because of the presence of alcohol in the blends which is highly volatile [22].

As ethanol fraction increases in the burning fuel, specific fuel consumption with respect to break power increases drastically with respect to diesel [23]. They endorsed this to ethanol's lower calorific value than that of the diesel fuel. The same trend was observed in $[24,25]$ as the addition of ethanol results in a lower heating value of the blend which in turn tends to increase the brake specific fuel consumption. BSFC reduces up to low speed of 2100 RPM and as engine speed increases BSFC also enhances for all ethanol-blended fuels [25]. They attributed this increase in the friction at higher speed and loads.

An elevated proportion of 'unchanged volume' combustion of ethanol blended fuels contributes to conversion efficiency with respect to break power increase slightly in evaluation with diesel [21]. They attributed this to the fast-premixed combustion part possessed by ethanol blends because of superior integration with the air for the period of ignition delay, oxygen enrichment. The BTE for ethanol incorporated fuel with different proportion reported about 1.1 to $1.9 \%$ improvement from no load to elevated load [24]. They attributed this to the increase in the oxygen content results in combustion improvement and reduce the warm up of the cylinder due to the little hotness of the flame front.

BTE reduces with an amplify ratio of the ethanol in the fuel blend and BTE is less than that of the diesel, biodiesel-diesel blends [25]. BTE increase to raise in the $\mathrm{CI}$ engine speed up to a certain point further 
amplify in the speed decreases the BTE [25]. They found that poor atomization during the premixed combustion phase is the cause for this trend. The high content of the oxygen reduces the chance of generating soot by fuel thick region, which leads to the reduction in smoke opacity at high loads [21]. Soot emissions from the ethanol blended fuels are considerably lower than the biodiesel-diesel blends at higher loads [24, 26]. They endorsed a reduction in the carbon content and supply of more oxygen for the blend by the ethanol addition was the reason for this trend.

As speed increases because of ethanol content of burning fuel, the chamber peak temperature and reaction time decreases, which results in the decrease in NOx emission [21]. The same trend was observed in the [23-25]. However, at higher speed increase in NOx emission was noticed [25, 26]. They explain that at higher speeds the fuel consumption is more, fast rate of burning of ethanol in the chamber results in greater peak temperature was the reason for this trend. At higher loads, the NOx emissions are considerable for the ethanol content burning fuels [22]. This may be caused by ethanol content in the burning fuel which is the major factor in increasing the NOx emissions.

At low load, amplified CO tail end emission was noticed which slightly lesser emission was at higher loads [21]. At low loads dramatic increase in CO emission was noticed, they attributed this to chamber temperature and ignition lag due to ethanol in the burning fuel. In contrast to the diesel-biodiesel blends, ethanol blended diesel-biodiesel mixture burns completely because of the increase in the oxygen content in the burning fuel [22, 24, 25].

The CO emissions increased as a percentage of ethanol and methanol concentration increases in the blend [23, 26]. A lesser certain number of the alcohol fuels leads to increase in ignition delay which results in the incomplete combustion may be the reason for the increase in $\mathrm{CO}$ emission trend.

A trend of increase in $\mathrm{CO}$ emission at higher speeds for the ethanol blended fuels was reported in [25]. At higher speed, decrease in the speed and temperature of fuel burning because of evaporative cooling was the reason for this trend.

In contrast to a biodiesel blend (B30), $\mathrm{HC}$ emission of biodiesel blend containing ethanol is slightly more [22]. It may because of easier evaporation of the diethyl ether and ethanol and 'slipped' into the cylinder. It was noticed that the higher oxygen content of ethanol is only helpful when the ethanol content is less than $10 \%$ otherwise it has a retarding effect on combustion in the form of cooling effect by ethanol [23]. Same increasing in HC emission trend was noticed in $[24,26]$ as compared to the biodiesel blend this may be because of higher latent heat of vaporization which produces lower evaporation phase by combustion chamber becomes cooler leading to the poor atomization may be the reason for the increasing $\mathrm{HC}$ emission.

\section{Objectives}

The objectives of the present work are as follows:

1.Modifying fuel properties of biodiesel incorporated diesel by using ethanol.

2.The problems of using biodiesel incorporated diesel and ethanol incorporated diesel in a diesel engine can be overcome by using both biodiesel and ethanol along with the diesel in compression ignition engine.

A block diagram of the proposed work has been represented in the Figure 1.

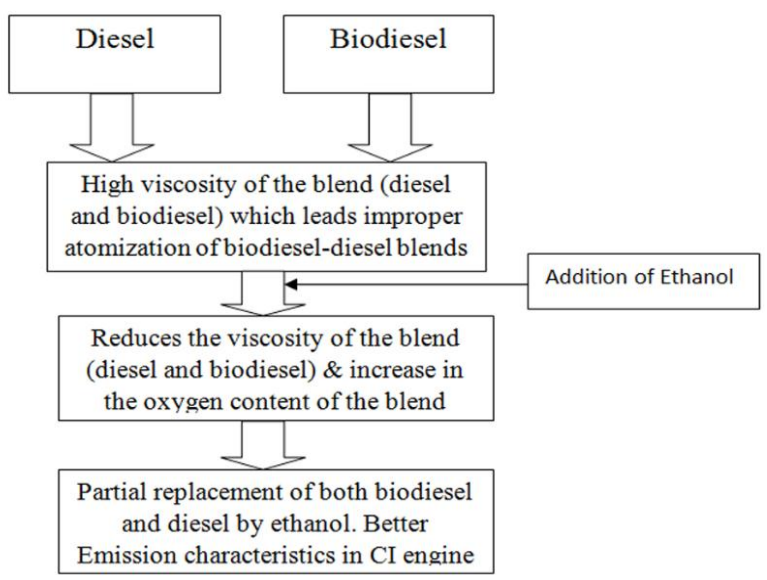

Figure 1 Block diagram of the work

\section{Resources and approach}

\subsection{Test engine setup}

Specification of devices and instruments used for emission test was listed in Table 1.

2.1.1 Engine details

Kirlosker made solo cylinder, 1500 RPM rated speed was used as test engine. Engine detail is mentioned in Table 1 (shown in Figure 2).

2.1.2 Torque measurement

Eddy current dynamometer, model MPA-40, has a maximum speed of 1500 RPM with the class F type 
of insulation was used to determine and measure the engine load and torque.

2.1.3 Emission tester
The AVL DIGAS 444N is to measure tail end emissions. Detail of AVL DIGAS 444N is mentioned in Table 1.

Table 1 Specification of devices and instruments

\begin{tabular}{lll}
\hline Devices and instruments & Parameter & Specification \\
\hline Engine & Cycle [stroke] & 4 \\
& Displacement [L] & $0.11 \mathrm{~m}$ \\
& Number of cylinders & 1 \\
& Bore & $0.08 \mathrm{~m}$ \\
& Compression ratio & 16.5 \\
Exhaust Gas Analyzers & Injection system & Mechanical Injection \\
& Intake system & Natural aspiration \\
& Make & AVL \\
& Type & AVL Digas 444 \\
& Power supply & $110 \mathrm{~V}-220 \mathrm{~V}$ 15 W \\
& CO Measuring Range & $0-0.15 \%$ Volume \\
Eddy Current Dynamometer & CO Measuring Range & $0-20 \%$ \\
& HC Measuring Range & $0-30000$ ppm Volume \\
& NO Measuring Range & $0-5000$ ppm Volume \\
& Make & Powermag Control Systems $(\mathrm{P})$ Ltd \\
& Type & FTAC \\
& Duty & S-1 \\
& Torque & $2.4 \mathrm{~kg}-\mathrm{m}$ \\
& RPM & $1500 \mathrm{rpm}$ \\
\hline
\end{tabular}

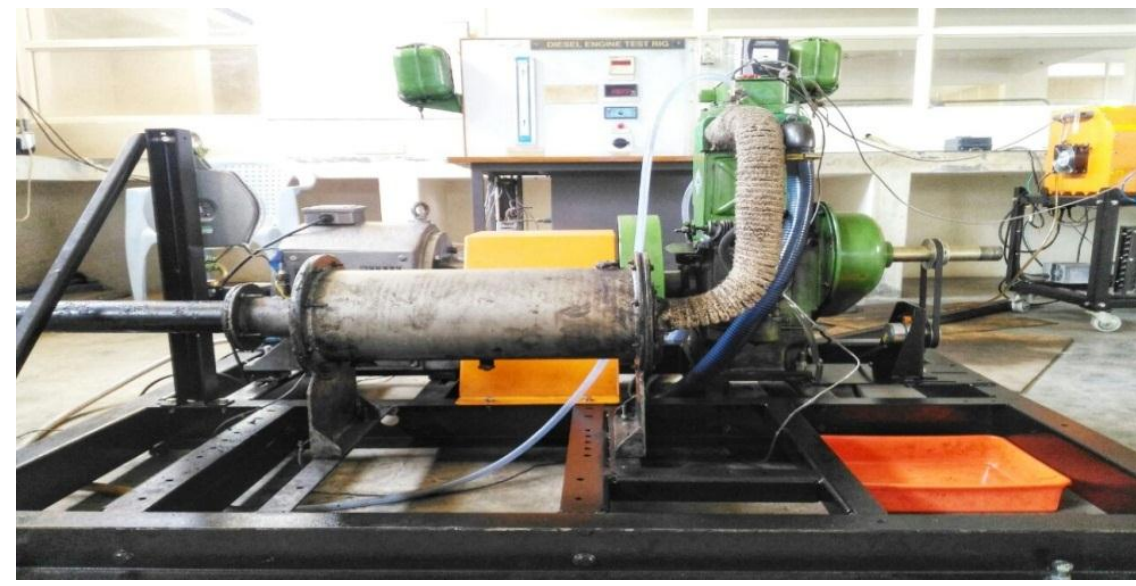

Figure 2 Engine test set up

2.2 Fuel preparation and samples characterization Diesel, Pongamia Biodiesel, and ethanol were used in the sample preparations. All the previous research in the field of biodiesel shown and proved that the B20 blend is the optimum blend for the CI engines in terms of the performance, combustion and emission characteristics. Hence two referral fuels B20 and diesel fuels were used for comparing the effect of ethanol on the performance, combustion and emission characteristics. Four fuels differing for the ethanol content were used in this study. Fuels samples were prepared by volume ratio as mentioned 65 in the Table 2. Soon after the preparation of the blends the thermal and physical properties were determined by using standard protocols. Properties of different blends used for testing of the emission characteristics of $\mathrm{CI}$ engine were tabulated in the Table 3 and Table 4.

\subsection{Experimental procedure}

An illustration of the experimental device is shown in Figure 3. For all experiment Eddy Current dynamometer reading, time taken for the $10 \mathrm{ml}$ of fuel consumption, exhaust gas and ambient 
temperature were recorded. On the exhaust side all the emissions were recorded by using an exhaust gas analyzer. Acquiring data and readings were taken for all the experiments after 15 minutes of start of the engine to ensure that no preceding fuel residue should left over in the fuel line. For all the fuel blends experiments were reciting for four times. After the reasoning and detail examinations of the result of finding of error, experiments were recited where ever it is necessary.

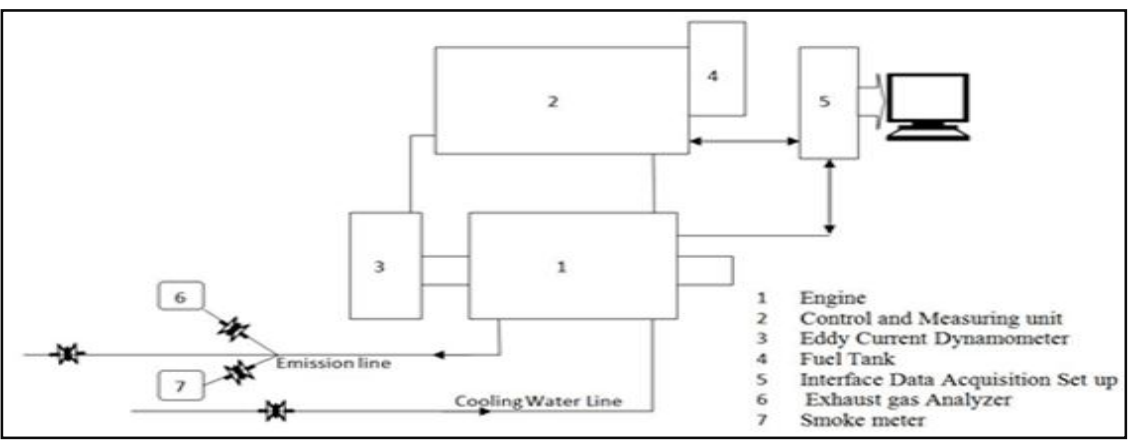

Figure 3 Experimental set up illustration

Table 2 Fuel preparation details

\begin{tabular}{llll}
\hline Name of the blend & Diesel (\%) & Pongamia biodiesel (\%) & Ethanol (\%) \\
\hline DB20 & 80 & 20 & - \\
DBE05 & 80 & 15 & 5 \\
DBE10 & 80 & 10 & 10 \\
DBE15 & 70 & 15 & 15 \\
DBE20 & 10 & 20 \\
\hline
\end{tabular}

Table 3 Properties of the three base fuels

\begin{tabular}{lllll}
\hline Properties & Units & Pongamia biodiesel & Ethanol & Diesel \\
\hline Density & $\mathrm{Kg} / \mathrm{m}^{3}$ & 840 & 749 & 850 \\
Kinematic viscosity & $\mathrm{Centistokes}(\mathrm{cst})$ & 5.14 & 2.2 & 4.2 \\
Flash point & ${ }^{0} \mathrm{C}$ & 128 & 17 & 76 \\
Fire point & ${ }^{0} \mathrm{C}$ & 134 & 26 & 65 \\
Calorific value & $\mathrm{KJ} / \mathrm{kg}$ & 37700 & 29700 & 44000 \\
\hline
\end{tabular}

Table 4 Properties of the different blends

\begin{tabular}{lllllll}
\hline Properties & Units & DB20 & DBE05 & DBE10 & DBE15 & DBE20 \\
\hline Density & $\mathrm{Kg} / \mathrm{m}^{3}$ & 808 & 820.2 & 811.7 & 809.4 & 796 \\
Kinematic viscosity & $\mathrm{Centistokes(cst)}$ & 17.026 & 5.25 & 4.23 & 3.52 & 3.159 \\
Flash point & ${ }^{\circ} \mathrm{C}$ & 86 & 27 & 27 & 27 & 27 \\
Fire point & ${ }^{\circ} \mathrm{C}$ & 96 & 37 & 35 & 33 & 31 \\
Calorific value & $\mathrm{KJ} / \mathrm{kg}$ & 42740 & 42340 & 41940 & 40910 & 40510 \\
Cetane number & - & 46.2 & 43.9 & 41.6 & 39.9 & 37.6 \\
\hline
\end{tabular}

\section{Results and discussion \\ NOx emission}

NOx emission is considered as extremely hazardous emission from diesel engine. Nitric Oxide (NO) \& Nitrogen Dioxide $\left(\mathrm{NO}_{2}\right)$ are the main elements of the NOx. The chamber temperature, oxygen proportion and time taken for the reaction to start were the causes of formation of NOx.
NO tail end loss of engine operating under different load revealed in Figure 4 for the different blends. For all blends nitric oxide emission is less than pure diesel this may be because of the increase in the percentage of oxygen, which is being contributed from both pongamia biodiesel and ethanol which further reduces the nitric oxide emission [21]. The same trend was observed in the [23-25]. Ethanol blended fuels shows the less emission as compared to the DB20 blend this may be because of low viscosity 
and higher oxygen content of the ethanol increases oxygen content in the blend and viscosity of the blend reduces. Reduced viscosity of the mixture promotes the better mixing, which increase the chamber temperature.

The increase of NOx with ethanol-blended fuel is more significant at high engine loads. This may be due to a higher load more amount of fuel is burnt at a faster rate, this may increase the engine peak temperature which may lead to increase in the NOx emission. Same increasing trend of NOx emission in higher ethanol content was observed by author [22] they attributed this increase in the oxygen content in the blend because of the presence of ethanol in the diesel biodiesel blend may be contributed to the increase in the NOx emission at elevated loads.

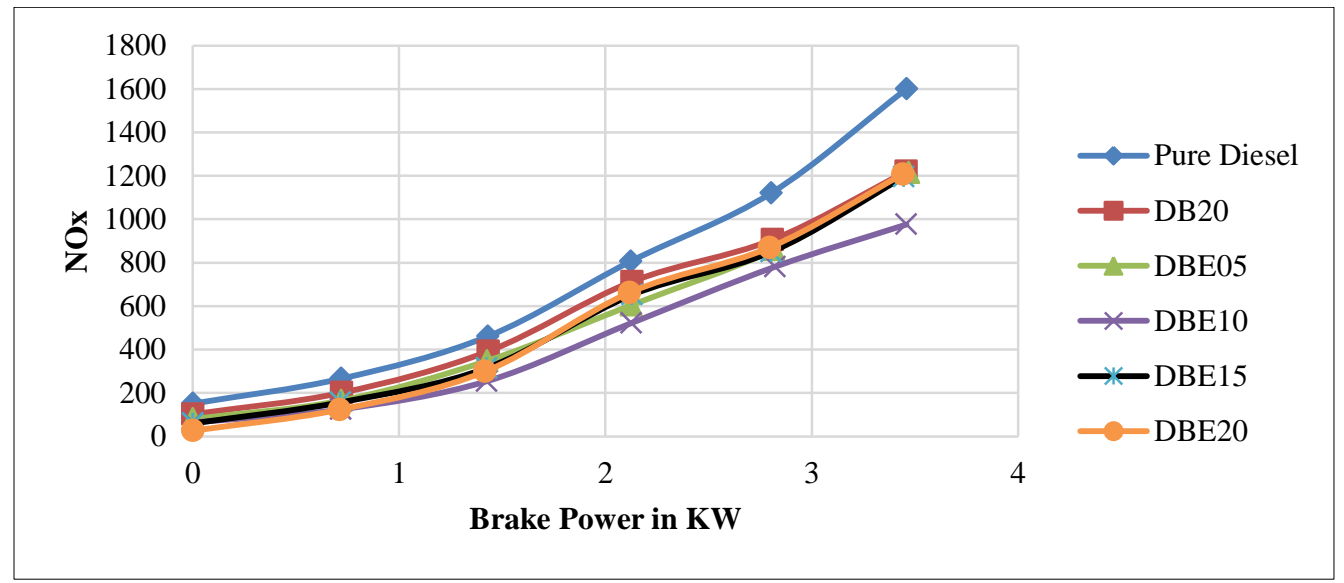

Figure 4 NOx emissions at different engine load

\section{$\mathrm{CO}$ and $\mathrm{HC}$ emissions}

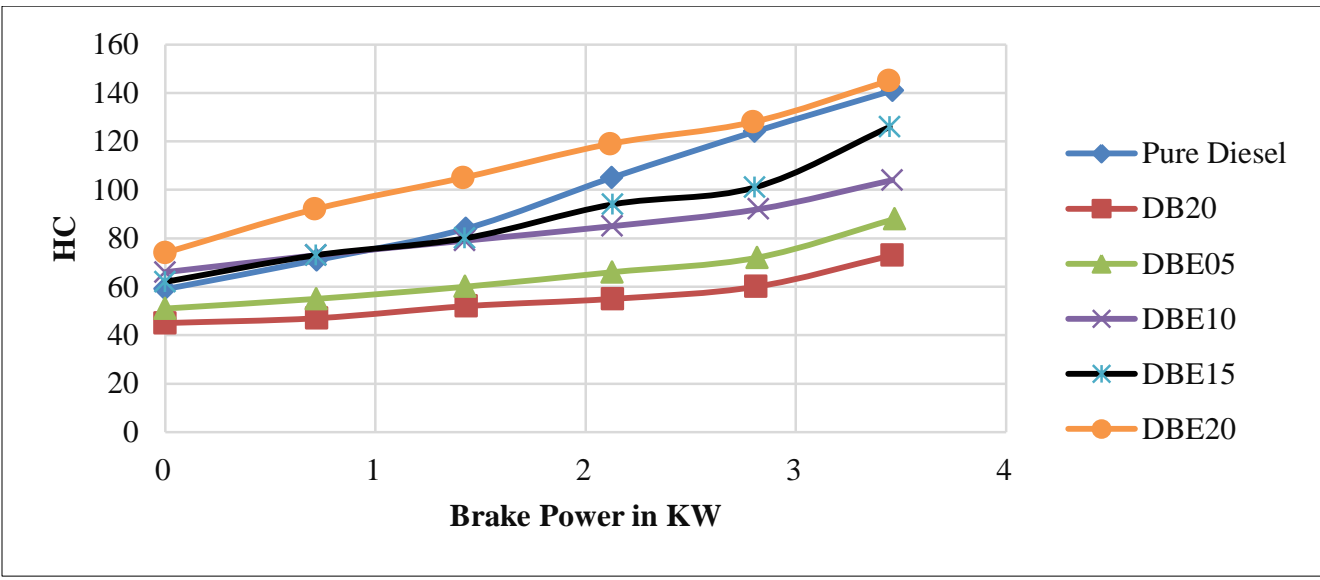

Figure 5 HC emissions at different engine load 


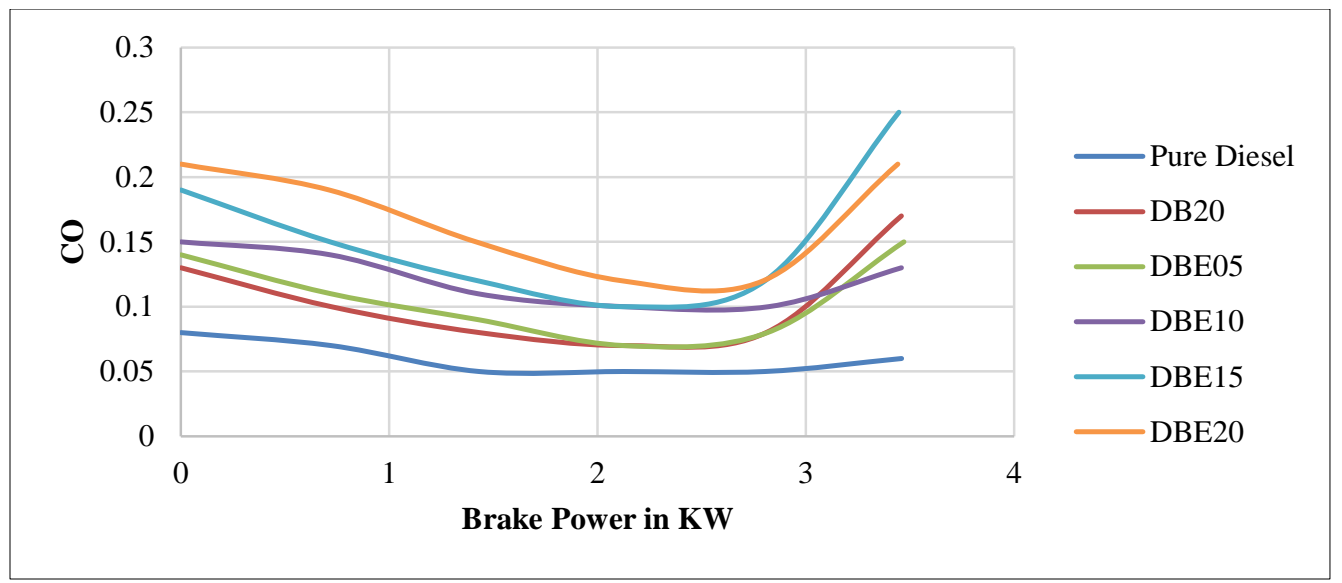

Figure $6 \mathrm{CO}$ discharges for engine operating under different loads

$\mathrm{HC}$ tail end loss is the result of partial burning of the hydrocarbon fuel. The $\mathrm{HC}$ tail end loss may be because of the lean and rich mixture during the before and after an ignition delay. Fuel present in the injector SAC volume was the reasons for the $\mathrm{HC}$ emissions. HC tail end loss of engine operating under different load revealed in Figure 5 for the different blends. In contrast to a biodiesel blend (B30), HC emission of biodiesel blend containing ethanol is slightly more. It may because of easier evaporation of the ethanol and 'slipped' into the cylinder. HC increased significantly as ethanol proportion increases this is because of the superior heat captivated per unit mass which produces the lower evaporation phase, thereby combustion chamber becomes cooler leading to the poor atomization may be the reason for the increasing $\mathrm{HC}$ emission. Same increasing $\mathrm{HC}$ emission trend was noticed in [22, 24, 26] relative to the biodiesel blended fuel. In [23] it was stated that the higher oxygen content of ethanol is only helpful when the ethanol content is less than $10 \%$ otherwise it has a retarding effect on combustion in the form of cooling effect by ethanol.

Leaner uniform mixture combustion which results in low chamber temperature results in the higher $\mathrm{CO}$ emission. At a low chamber temperature, the intermediary product of combustion $\mathrm{CO}$ cannot fully covert to $\mathrm{CO}_{2}$. $\mathrm{CO}$ emission level for various engine parameters is shown in Figure 6 for different fuel mixture. For all ethanol incorporated burning fuels the $\mathrm{CO}$ tail end discharge is higher with respect to petroleum diesel and diesel-biodiesel blend.

At low load $\mathrm{CO}$ emission amplified whereas the peak $\mathrm{CO}$ emission slightly decreases with reference to diesel. For ethanol incorporated burning fuel, $\mathrm{CO}$ tail end discharge increase with amplified in the proportion of ethanol. This may be because of lower cetane number of the ethanol blended burning fuels, which in turn amplifies the ignition lag results in imperfect combustion. Same trend was noticed by $[23,26]$. CO emission increased at higher loads for the ethanol blended fuels. This may be because of the evaporative cooling at higher loads leads to the decrease in the burning velocity and temperature was the reason for this trend [25].

\section{Opacity}

Opacity is the extent to which visibility of a backdrop (i.e., Blue sky) is reduced by particulates (smoke). The smoke opacity levels for test blends for various engine operating condition are as shown in Figure 7. As engine load increases, smoke opacity also increases. But for the higher concentration blends, smoke opacity is somewhat superior with respect to diesel fuel for lower loads. Higher smoke opacity may be because ethanol has a higher heat absorption per $\mathrm{kg}$ of fuel, which results in the slower evaporation which in turn results in a decline in the chamber temperature. The decline in the chamber temperature slows down the soot oxidation rates, which result in an increase in the smoke opacity.

Advantage of boost in the $\mathrm{O}_{2}$ because of addition of ethanol results in reduction of soot formation $[21,24$, 26] were not followed, thereby these experiments reduced in the combustion chamber temperature may play a major role in increase the soot emission which in turn increases the opacity. 


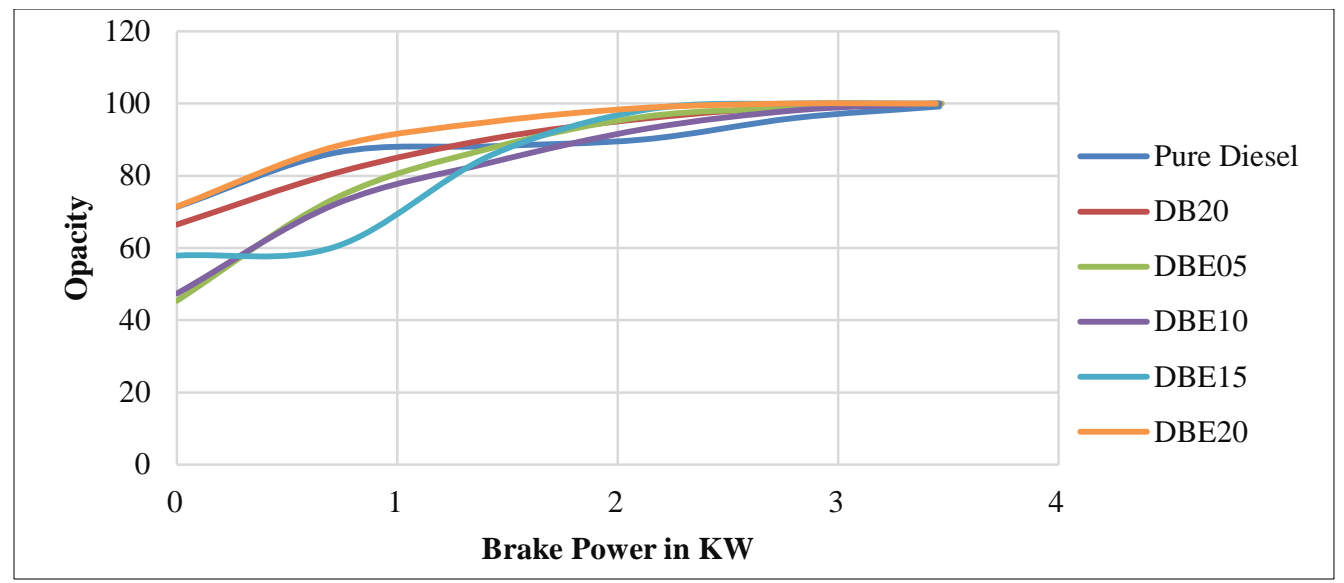

Figure 7 Smoke opacity levels of the test blends for various engine operating condition

\section{Conclusions}

Assessment of ethanol as fuel additive to biodiesel incorporated diesel burning fuel on tail end emission characteristics in compression ignition engine has been reported in the paper. Pongamia Biodiesel drastically improves the ethanol solvency in the diesel fuel. Oxygen content of the blend increases, which helps in complete combustion and reduction in the peak temperature of the combustion. Engine emissions are function of engine operating parameters like load, speed and ethanol percentage in the blend. Ethanol presence has a positive effect like increase in the oxygen content, where as its presence lead to the cooling of fuel mixture during the combustion which reduces the chamber temperature.

For all blends nitric oxide emission is less than pure diesel this may be because of the increase in the percentage of oxygen, which is being contributed from both pongamia biodiesel and ethanol which further reduces the nitric oxide emission.

In contrast to a biodiesel blend, $\mathrm{HC}$ emission of biodiesel blend containing ethanol is slightly more. $\mathrm{HC}$ emission increased considerably with increase in share of ethanol in burning fuel. Since ethanol needs more heat to vaporize which produce poor evaporation phase, thereby the chamber becomes cooler leading to the poor atomization may be the reason for the increasing $\mathrm{HC}$ emission.

The $\mathrm{CO}$ emissions increased as ethanol concentration increases in the burning fuel. Ethanol, which is a low cetane number amplifies the ignition delay of the burning fuel which results in imperfect combustion.

$\mathrm{CO}$ emission increased at higher loads for the ethanol blended fuels. This may be because of the evaporative cooling at higher loads leads to the 69 decrease in the burning velocity and temperature was the reason for this trend.

As engine load increases, smoke opacity also increases. But for the higher concentration blends, smoke opacity is slightly higher than that of mineral diesel at lower loads. Higher smoke opacity may be because of ethanol, which has a higher latent heat of vaporization which results in the slower evaporation which in turn leads to decrease in the chamber temperature. The decrease in the chamber temperature slows down the soot oxidation rates, which result in an increase in the smoke opacity.

In future ethanol may be used as fuel additive for tertiary (two different type of biodiesel blended with diesel) blends may be carried out to ascertain the tail end emission characteristics in compression ignition engine.

\section{Acknowledgment}

None.

\section{Conflicts of interest}

The authors have no conflicts of interest to declare.

\section{References}

[1] https://www.bp.com/content/dam/bp-country/ de_ch/ PDF/bp-statistical-review-of-world-energy-2017-fullreport.pdf. Accessed 6 December 2018.

[2] https://www.bp.com/content/dam/bp/businesssites/en/global/corporate/pdfs/energyeconomics/statistical-review/bp-stats-review-2018full-report.pdf. Accessed 6 December 2018.

[3] Janaun J, Ellis N. Perspectives on biodiesel as a sustainable fuel. Renewable and Sustainable Energy Reviews. 2010; 14(4):1312-20.

[4] Shahir SA, Masjuki HH, Kalam MA, Imran A, Fattah IR, Sanjid A. Feasibility of diesel-biodiesel- 
ethanol/bioethanol blend as existing CI engine fuel: an assessment of properties, material compatibility, safety and combustion. Renewable and Sustainable Energy Reviews. 2014; 32:379-95.

[5] Cataluña R, Da Silva R. Effect of cetane number on specific fuel consumption and particulate matter and unburned hydrocarbon emissions from diesel engines. Journal of Combustion. 2012.

[6] Adaileh WM, AlQdah KS. Performance of diesel engine fuelled by a biodiesel extracted from a waste cocking oil. Energy Procedia. 2012; 18:1317-34.

[7] Agarwal AK. Biofuels (alcohols and biodiesel) applications as fuels for internal combustion engines. Progress in Energy and Combustion Science. 2007; 33(3):233-71.

[8] Lee CS, Park SW, Kwon SI. An experimental study on the atomization and combustion characteristics of biodiesel-blended fuels. Energy \& Fuels. 2005; 19(5):2201-8.

[9] Sahoo PK, Das LM. Combustion analysis of Jatropha, Karanja and Polanga based biodiesel as fuel in a diesel engine. Fuel. 2009; 88(6):994-9.

[10] Deshmukh D, Mohan AM, Anand TN, Ravikrishna RV. Spray characterization of straight vegetable oils at high injection pressures. Fuel. 2012; 97:879-83.

[11] Hulwan DB, Joshi SV. Performance, emission and combustion characteristic of a multicylinder DI diesel engine running on diesel-ethanol-biodiesel blends of high ethanol content. Applied Energy. 2011; 88(12):5042-55.

[12] Hardenberg HO, Schaefer AJ. The use of ethanol as a fuel for compression ignition engines. SAE Technical Paper; 1981.

[13] Weidmann K, Menrad H. Fleet test, performance and emissions of diesel engines using different alcoholdiesel fuel blends. SAE Transactions. 1984; 93(5):800-13.

[14] De Caro PS, Mouloungui Z, Vaitilingom G, Berge JC. Interest of combining an additive with diesel-ethanol blends for use in diesel engines. Fuel. 2001; 80(4):565-74.

[15] He BQ, Shuai SJ, Wang JX, He H. The effect of ethanol blended diesel fuels on emissions from a diesel engine. Atmospheric Environment. 2003; 37(35):4965-71.

[16] Rakopoulos DC, Rakopoulos CD, Kakaras EC, Giakoumis EG. Effects of ethanol-diesel fuel blends on the performance and exhaust emissions of heavy duty DI diesel engine. Energy Conversion and Management. 2008; 49(11):3155-62.

[17] Park SH, Youn IM, Lee CS. Influence of ethanol blends on the combustion performance and exhaust emission characteristics of a four-cylinder diesel engine at various engine loads and injection timings. Fuel. 2011; 90(2):748-55.

[18] Broukhiyan EM, Lestz SS. Ethanol fumigation of a light duty automotive diesel engine. SAE Technical Paper; 1981.

[19] Hayes TK, Savage LD, White RA, Sorenson SC. The effect of fumigation of different ethanol proofs on a turbocharged diesel engine. SAE Technical Paper; 1988.

[20] Cetin M, Yüksel F, Kuş H. Emission characteristics of a converted diesel engine using ethanol as fuel. Energy for Sustainable Development. 2009; 13(4):250-4.

[21] Hulwan DB, Joshi SV. Performance, emission and combustion characteristic of a multicylinder DI diesel engine running on diesel-ethanol-biodiesel blends of high ethanol content. Applied Energy. 2011; 88(12):5042-55.

[22] Qi DH, Chen H, Geng LM, Bian YZ. Effect of diethyl ether and ethanol additives on the combustion and emission characteristics of biodiesel-diesel blended fuel engine. Renewable Energy. 2011; 36(4):1252-8.

[23] Yilmaz N. Comparative analysis of biodiesel-ethanoldiesel and biodiesel-methanol-diesel blends in a diesel engine. Energy. 2012; 40(1):210-3.

[24] Saleh HE, Selim MY. Improving the performance and emission characteristics of a diesel engine fueled by jojoba methyl ester-diesel-ethanol ternary blends. Fuel. 2017; 207:690-701.

[25] Tan YH, Abdullah MO, Nolasco-Hipolito C, Zauzi NS, Abdullah GW. Engine performance and emissions characteristics of a diesel engine fueled with dieselbiodiesel-bioethanol emulsions. Energy Conversion and Management. 2017; 132:54-64.

[26] Emiroğlu AO, Şen M. Combustion, performance and exhaust emission characterizations of a diesel engine operating with a ternary blend (alcohol-biodieseldiesel fuel). Applied Thermal Engineering. 2018; 133:371-80.

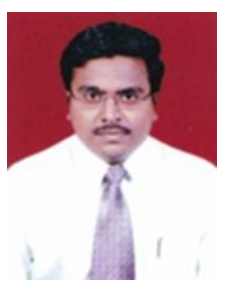

K. Rajesh is currently working as an Associate Professor at STJ Institute of Technology, Ranebennur, Karnataka. He completed his M.Tech in Thermal Power Engineering from Visvesvaraya Technological University, Belgaum. His total teaching experience is 15 Years. Currently, he is pursuing Ph.D. in Mechanical Engineering from Visvesvaraya Technological University, Belgaum.

Email: rajeshkodbal@gmail.com

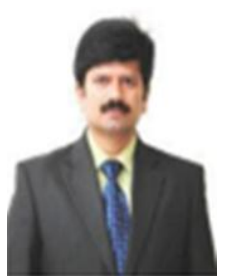

Dr. Ganesh D.B is currently working as a Professor and Dean, R \& D at GM Institute of Technology, Davangere, Karnataka. He completed his M.Tech in Heat Power Engineering from KREC, Surathkal and Ph.D. in Mechanical Engineering from Visvesvaraya Technological University, Belgaum. $\mathrm{He}$ is a National Executive Council Member of Indian Society for Technical Education, New Delhi. His total teaching experience is 25 Years. He is presently guiding $08 \mathrm{Ph}$.D. students. 